İş ve İnsan Dergisi I The Journal of Human and Work

Y11 | Year: Nisan | April 2021

Cilt-Sayı | Volume-Issue: 8 (1)

ss I pp: 49-58

doi: 10.18394/iid.745886

e-ISSN 2148-967X

http://dergipark.gov.tr/iid/

Araştırma Makalesi

\title{
İzlenim Yönetimi Taktiklerinde Bireysel Performans Algısının Rolü: Kamuda Bir Araştırma
}

\author{
The Role of Individual Performance Perception in Impression Management Tactics: \\ A Study in Public Institution
}

Alper Bahadır Dalmış ${ }^{\mathrm{a}}$

MAKALE BILGISII

Anahtar Kelimeler:

İletişim,

İlenim Yönetimi,

İzlenim Yönetimi Taktikleri,

Performans,

Performans Algisı.

Tarihler :

Geliș 31 Mayıs 2020

Kabul 15 Ekim 2020

\section{ÖZ}

İzlenim yönetimi taktikleri örgüt üyelerinin diğer üyeler üzerinde yarattılart izlenimi yönetme yöntemleri tanımlanabilir. Bireylerin amaçlarına ulașmak için kullandıkları izlenim yönetimi taktikleri kendini sevdirme, niteliklerini tanıtma, örnek olma, gözdă̆l verme ve kendini acındırma olmak üzere bes farklı boyut altında incelenmektedir. Bireysel performans alglsi örgüt üyelerinin kendi performanslarını nasıl değerlendirdiklerini ölçmektedir. Bu araştırmanın amacı bireysel performans algısının izlenim yönetimi taktikleri üzerindeki etkisini ölçmektir. Araştırmanın örneklemi 315 çalışandan oluşmaktadır. Veri toplama amacıyla oluşturulan anket formu demografik bilgi formu, izlenim yönetimi taktikleri ölçeği ve bireysel performans algısı ölçeğinden oluşmaktadır. SPSS (Versiyon 22.00) istatistik paket programı kullanılarak yapılan analiz ile bireysel performans algisinin izlenim yönetimi taktiklerinden örnek olma, kendini sevdirme ve niteliklerini tanitma boyutlarını anlamlı ve pozitif yönde etkilediği sonucuna ulaşılmıştır.

\section{ARTICLE INFO}

\section{Keywords:}

Communication,

Impression Management Impression Management

Tactics,

Performance,

Performance Perception.

Article history:

Received 31 May 2020

Accepted 15 October 2020

\begin{abstract}
A B S T R AC T
Impression management tactics are defined as organizing the impression that members of the organization make on other people. Impression management tactics, which are observed in five different dimensions, namely ingratiation, introducing self-quality, intimidation, being exemplary and self-pity, is a method that employees use to achieve their goals. Individual performance perception is based on how employees evaluate their own performance. The aim of this research is to examine the effect of individual performance perception on impression management tactics. The research sample consists of 315 workers. The questionnaire form consists of demographic information scale, impression management tactics scale and individual performance perception scale. As a result of the analyzes made using the SPSS (Version 22.00), it was concluded that the perception of individual performance positively and significantly affects the dimensions of ingratiation, introducing self-quality and being exemplary, and have no effect on tactics of intimidation and self-pity.
\end{abstract}

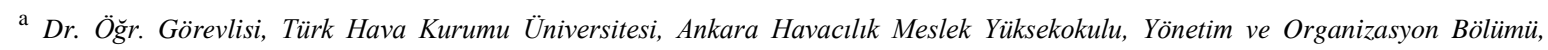
Ankara, Türkiye, alperdalmis@hotmail.com, ORCID: 0000-0002-9069-3917.
} 


\section{GİRIŞ}

Örgüt hedeflerine ulaşılabilmesi için verimli ve etkin bir şekilde kullanılması gereken kaynaklardan en önemlisi örgütün personelleridir. Örgütler çalışanlardan yüksek performans beklerken çalışanlar da örgütlerinden maddi veya manevi birtakım beklentilerini karşılama amacıyla örgütsel faaliyetlerde bulunurlar. Türk Dil Kurumu'na (2020) göre "Bir durum veya olayın duyular yolu ile insan üzerinde bıraktığı etki, intiba, imaj” olarak tanımlanan izlenim kavramı, örgüt üyeleri için de önem taşımaktadır, çünkü üyeler arası iletişimde bireyler ister istemez izlenim sahibi olmakta ve diğerlerine karşı bir izlenim oluşturmaktadır. İzlenim yönetimi kavramı psikoloji, sosyoloji ve örgütsel davranış başta olmak üzere pek çok sosyal disipline konu olmuş bir kavramdır (Akgün, 2009).

Günümüzde etkili iletişimin temeli olarak görülen izlenim yönetimi toplumun büyük bir çoğunluğunun örgüt içerisinde ve sosyal ilişkilerinde yaygın bir şekilde kullandığı doğal bir iletişim aracı olarak görülmektedir (Özdemir, 2006). Örgüt üyeleri arasında sözlü ve sözsüz olarak gerçekleşen iletişim kanalları vasıtasıyla kullanılan izlenim yönetimi taktikleri, örgüt üyelerinin diğer insanları etkileme ve birbirleri ile olan ilişkilerini yönetmeleri amacı ile kullanılmaktadır. İzlenim yönetimi sürecinde bireylerin diğer insanların kendileri hakkında ne düşündüğünü yönetme amacı taşımaktadırlar (Rosenfeld \& Giacalone \& Riordan, 1995). Örgüt üyeleri oluşturdukları bu izlenimleri yönetmek ve/veya herhangi bir izlenimin faydalarına olacağ düşüncesiyle izlenim oluşturmak amaciyla izlenim yönetimi taktiklerini kullanmaktadırlar. Öte yandan, performans ise örgüt üyelerinin örgüte katkı yapma derecelerini gösteren önemli bir ölçüttür. Her ne kadar performansın ölçümü ve değerlendirilmesi konusunda birbirinden farklı yaklaşımlar bulunsa da alan yazını taramasında kendini sevdirme ve niteliklerini tanıtma gibi bazı izlenim yönetimi taktiklerinin performans değerlendirmesi üzerinde anlamlı ve pozitif bir etki bıraktığı gözlemlenmiştir.

Çalışanların izlenim yönetimi taktiklerini kullanması ve bu taktiklerden hangisini seçeceği konusunda bireysel performans algılarının önemli olduğu düşünülmektedir. $\mathrm{Bu}$ temel varsayım, bireylerin kendileri hakkında ne düşündükleri ile diğer insanlara karşı yansıttıkları imaj arasında bir bağlantı olduğu fikrine dayanmaktadır. Örneğin, bireysel performans algısı yüksek olan bir birey, kendi performansını yeterli gördüğü için izlenim yönetimi taktiklerinden olan niteliklerini tanıtma yöntemine başvurabilir. Böylelikle kendisini performans açısından yeterli ve yüksek seviyede gören bireyin bu yeterliliğini diğer örgüt üyelerine gösterme motivasyonuna sahip olması beklenebilir. Tam tersi bir şekilde kendisini acındırma izlenim yönetimi taktiğinin performans algısı yüksek bir insan tarafından kullanılması beklenmemektedir çünkü performans algısı yüksek olan bireyin diğer insanlardan yardım alma ihtiyacı hissetmesi doğal bir durum değildir.

Kamu kuruluşları da özel sektör firmaları gibi emek yoğun hizmet üreticileri olarak örgütsel davranış alan yazınında sıklıkla araştırmalara konu olan örgütler olmaktadır. Örgütsel davranış alanının konusunu oluşturan pek çok kavramın kamu kuruluşlarında sıklıkla incelendiği göz önünde bulundurularak bu araştırmada Ankara'da bulunan Türkiye Kömür İşletmeleri örneklem olarak seçilmiş ve ile bireysel performans algısının izlenim yönetimi taktikleri üzerindeki etkisinin saptanması hedeflenmiştir.

\section{KAVRAMSAL ÇERÇEVE}

\section{1. İzlenim Yönetimi Kavramı}

Sosyal bilimlerde izlenim yönetimi, insanların diğer insanların onları algılayış şeklini etkilemeye çalıştıkları süreçleri ifade eder. Çevresiyle sürekli bir etkileşim ve iletişim içerisinde olan insanlar diğer bireylere karşı bilinçli veya bilinçsiz olarak birer izlenim oluştururlar. $\mathrm{Bu}$ izlenimlerin bilinçli olarak yönetilmesi de izlenim yönetimi olarak adlandırılmaktadır. İzlenim yönetimi, bireylerin diğer bireyler nezdinde izlenimlerini kontrol etme süreci olarak tanımlanabilir (Robbins \& Judge, 2015). İlk olarak Goffman'ın (1959) "günlük hayatta bireyin benlik sunumu" isimli kitabında tanımlanan izlenim yönetimi, bireylerin etkileşimlerini yönetme amacıyla ortaya koydukları davranışlar bütünü olarak ele alınmaktadır. $\mathrm{Bu}$ davranışlar diğer bireyler üzerinde olumlu ve uygun imajların yaratılabilmesi amacıyla kullanılmaktadır. (Zerbe \& Paulhus, 1987). Bireyler arası her türlü etkileşimi kapsamayan izlenim yönetimi, iletişim esnasında bir bireyin diğer birey veya bireyler üzerinde belirli bir imaj oluşturma çabası ile bulunduğu davranışları kapsamaktadır. Örgüt içerisinde izlenim yönetimi çalışanlar tarafından amirlerinin onlara olan tutumlarını, yaklaşımlarını ve davranışlarını etkilemek amacıyla kullanılmaktadır (Yu, 2019).

Literatürde çalışanların örgütün ve diğer çalışanların ortak değer ve seçimlerini baz alarak izlenim yönetimi taktikleri uyguladığını gösteren pek çok çalışma bulunmaktadır (Arkin, \& Shepperd \& Giacalone \& Rosenfeld, 1989; Peck \& Hogue, 
2018). Bu açıdan bakıldığında izlenim yönetiminin çalışanlar tarafından sıklıkla uygulanan ve çalışanlar arasındaki iletişimi önemli derecede etkileyen bir etmen olarak ele alınması gerektiği görülmektedir. İzlenim yönetimi, yöneticilerin astlarının performansını değerlendirirken önemli ölçüde etkilendikleri bir alan olarak görülmektedir. $\mathrm{Bu}$ nedenle izlenim yönetimi, bireyler ve örgütler tarafından iş hayatını ve geleceği olumlu yönde etkileyebilecek bir taktikler bütünü olarak ele alınabilir (Montagliani \& Giacalone, 1998). İzlenim yönetimi örgütsel vatandaşlık kavramı ile ilişkilendiren çalışmalar (Bolino, 1999; Yu, 2019) bulunduğu gibi; performansla ilişkili olan terfi etme, kariyer gelişimi, işe alınma gibi alanlarla ilişkilendiren çalışmalar da bulunmaktadır (Bourdage \& Wiltshire \& Lee, 2015).

\section{2. İzlenim Yönetimi Taktikleri}

İzlenim yönetimi taktikleri farklı araştırmacılar tarafından farklı şekillerde sınıflandırılmalara tabii tutulmuştur. Bu çalışmada Jones ve Pittman'ın (1982) ortaya atmış oldukları izlenim yönetimi taktikleri kullanılmış, bu taktikler bir bireyin diğer bir birey veya bireyler üzerinde etkili olma ve onları manipülasyon etme amaçlarıyla uyguladıkları davranışlar olarak tanımlanmıştır. Bu taktikler, literatürde en sik incelenen yönetim taktikleri olmaları nedeniyle seçilmiştir.

Kendini Sevdirme. Yağcılık olarak da adlandırılan kendini sevdirme izlenim yönetimi taktiği, bireyin ortama uygun ve ortamda sevilebileceğini düşündüğü kişi olmak için uygun davranışlar sergileyerek amirini veya iş arkadaşlarını etkilemeye çalışmasıdır. Kendini sevdirme genellikle, amirini övme, görüş ayrılığ 1 yaşamama (sürekli bir onaylama hali), başkalarına iyilik yapma ve başkalarını övme yöntemleriyle gerçekleştirilmektedir (Jaja, 2003). Yapılan bir araştırma sonucunda kendini sevdirme izlenim yönetimi taktiğini uygulayan çalışanların ücret artışı, terfi alma ve performans değerlendirmesi gibi olumlu çıktılar yönünden bu taktiği kullanmayan çalışanlara oranla daha önde olduğu görülmüştür (Gardner, 1992).

Niteliklerini Tanıtma. Bu taktikte birey sahip olduğu yetkinlikleri ve ulaştığı başarıları sürekli olarak etrafına anlatarak kendisinin başarılı bir çalışan olduğunu göstermeye çalışmaktadır. Özellikle işe alım süreçlerinde daha fazla kullanılan bu taktik, başarılı olması durumunda taktiği kullanan bireyin taktiğine devam etmesine sebep olmaktadır. $\mathrm{Bu}$ taktik uyarınca bireyler genel yetenek ve özelliklerinin diğer insanlar tarafindan yeterli seviyede olduğunun algılanmasını amaçlarlar. Bu sayede bireyler terfi ve ücret artışı gibi olumlu çıtılar elde etmeyi hedeflerler (Çetin \& Basım, 2010).

Gözdă̆ı Verme. Yildırma olarak da adlandırılabilecek bu taktik bireyin diğer birey veya bireyler üzerinde korkutma ve güç kullanmaktan çekinmeme izlenimi vererek etki altında bırakmasıdır. Genellikle örgüt içerisinde ast ve üstler arasında gerçekleşen bu yöntem işlerin ilerleyişini sağlasa da yıldırma taktiği uygulayan kişinin sevilmemesine yol açmaktadır. Genellikle gücü elinde bulunduranların uygulamış olduğu bu taktik ile kendini sevdirmenin tam tersi bir şekilde karşıdakilerin sevgisini kazanma önemsenmemekte ve korku ile itaat kavramları ön plana çıkmaktadır (Doğan \& Kılıç, 2009).

Örnek Olma. Bu taktik genellikle ahlaki sorumlulukları abartarak ve diğer insanlara bu yönde ögütler verme veya örnek davranışlar gösterdiğini insanlara gösterme yoluyla olur. Örneğin, çalışan işe herkesten önce gelir ve herkesten sonra çıktığını diğer çalışanlara gösterme merakı taşır. $\mathrm{Bu}$ yol ile amiri üzerinde olumlu bir etki bırakmanın yanı sıra diğer çalışanlar üzerinde baskı sağlanmış olur. Örnek olma taktiği ile örgütü için çalışkan ve fedakarlık yapmaktan çekinmeyen bir imaj çizilerek diğer çalışanlar üzerinde öyle olmadıkları için suçluluk duygusu hissetmeleri amaçlanır. $\mathrm{Bu}$ nedenle bu taktiği kullanan bireylerin, amirleri tarafından uygun görülseler de diğer çalışanlar tarafından olumsuz değerlendirilmelerine neden olabilir (Toptan, 2014).

Kendini Acındırma. Yardım isteme olarak da adlandirılan bu taktikte birey kendisini yetersiz göstererek işlerinde yardım almayı hedeflemektedir. Niteliklerini övmenin tam tersi olan bu yöntemde bireyler işten kaytarma amaciyla yetersiz olduğu imajını kullanır. $\mathrm{Bu}$ yöntemin sık s1k kullanılması kişinin istenmeyen kişi olmasına neden olabilir. Yani bu taktik kısa dönemde başarılı olsa da uzun dönemde bireyin ortamdan uzaklaştırılmasına neden olabilir (Doğan ve Kılıç, 2009).

\subsection{Bireysel Performans Algısı}

Örgütlerin en önemli hedeflerinden birisi üyelerinden yüksek performans alabilmektir. Pek çok farklı açıdan ele alınabilen ve değerlendirilebilen bireysel performansın uygun bir biçimde ölçülebilmesi ve örgütün çalışanlarından ne derecede etkin ve verimli faydalanabildiğinin belirlenebilmesi günümüzde örgütlerin en önemli sorunsallarından birisidir (Akçakanat, 2009). Farklı şekillerde tanımlanan performans kavramı, işin yerine getirilirken çalıșanın davranış biçimi ve işi yerine getirme şekli ve süresi olarak tanımlanmaktadır (Tunçer, 2013). Bir çalışanın, işi 
yaparken verimli ve etkin olması veya işin sonuçlarının uygun olması gibi anlamları da olan performans kavramı, genel itibarıyla çalışanların yetkinliklerini gösteren bir kavramdır. Performans kavramı birey, grup ve örgüt bazında ele alınabilse de grup ve örgüt performansının da en önemli belirleyicisi bireysel performanstır (Çöl, 2008). Performans, diğer bir tanıma göre bireyin hedeflerine ulaşıp ulaşmama durumu ve/veya hedeflere ulaşırken kullandığ değerlendirilmesidir (Luecke, 2008).

Performans kavramı yalnızca bir çalışanın işi ne kadar sürede ne kadar kaynak kullanarak ve uygun bir şekilde yapıp yapmadığı ile ilgili değildir. $\mathrm{Bu}$ olgulara ek olarak performans, çalışanın işini yaparken çevresiyle kurduğu iletişim ve davranış şekilleri de önem kazanmaktadır. $\mathrm{Bu}$ araştırmada kullanılan bireysel performans alg1s1 kavramı Borman ve Motowidlo (1993) tarafindan geliştirilen iki boyutlu performans anlayışını yansıtmaktadır. $\mathrm{Bu}$ yaklaşıma uygun olarak, performans görev performansı ve durum performans olmak üzere iki boyut altında incelenmektedir.

Görev Performansı, örgütün temel amaçlarını ve bu amaçlarına ulaşmaya yardımcı olan faaliyetlerin tümünü kapsamaktadır. Örneğin, bir imalathanede temel görev imalatın sağlanması iken, görev performansında bunlara ek olarak gerekli teknik ve insan kaynakları işlemlerinin sağlanması da görev performansı kapsamına girmektedir. Çevresel performans ise teknik olmayan tüm işlemlerin sağlanması olarak tanımlanabilir. Örgüt içinde bireyin örgüt ile ve diğer çalışanlar ile nasıl iletişim kurduğu ile ilgili olan bu boyut, çalışanın örgüt içinde yardımsever olması, fazladan özveri göstermesi, örgüte bağlılık sunması gibi davranışlar çevresel performans alanına girmektedir (Borman \& Motowidlo, 1993).

Etkinlik ve verimlilik performansın temel belirleyicileri olan kavramlardır. Verimlilik bir işte kullanılan girdiler ile çıktılar arasındaki oranı ifade ederken, etkinlik belirlenen hedeflere ulaşabilme yetisini ifade etmektedir. Örneğin, bir personele belirli bir işi yapabilmesi için önceden belirlenmiş bir zamanda işin bitirilmesi, verimliliğe işaret ederken, işin doğru ve düzgün bir şekilde bitirilmesi etkinliğe işaret etmektedir. Etkinlik ve verimlilik kavramları bireysel performansın en önemli göstergelerinden birisidir. Sonuç olarak, performans kavramı örgüt üyelerinin önceden belirlenmiş olan amaçlara ulaşıp ulaşmaması ve ulaştığı durumda hangi koşullar altında ve ne kadar kaynak kullanarak ulaştığı ile ilgili bir kavramdır.

\section{YÖNTEM}

\subsection{Araştırmanın Hipotezi}

Alan yazını incelendiğinde izlenim yönetiminin uygun bir şekilde sağlanması durumunda yöneticilerin performansında önemli bir artış olduğu görülmektedir. Başarılı bir yönetici olmanın doğru kararlar almak ile ilgisi olduğu kadar yöneticinin çalışanlar gözünde nasıl bir imajı olduğu ile de ilgilidir. Yapılan başka bir araştırmada izlenim yönetimi taktiklerinin çalışanların performansını ve performans değerlemelerini artırarak onların terfi etmesinde önemli bir yer tuttuğu belirtilmiştir (Singh \& Vinnicombe, 2001). Yöneticileri tarafından performans değerlendirme sırasında öne çıkmak isteyen çalışanların izlenim yönetimi taktiklerini kullanmanın avantajlarından haberdar olduğunu varsaymak makul bir çıkarım olabilir (Jain, 2012).

İzlenim yönetimi taktikleri işe alım, performans değerlendirme ve kariyer hedeflerine ulaşma gibi pek çok noktada önemli etkileri bulunan bir kavramdir (Bolino \& Kacmar \& Turnley \& Gilstrap, 2008). İzlenim yönetimi taktiklerinden olan kendini sevdirme taktiğinin kariyer başarısı anlamında pozitif yönde ve olumlu bir etkisi olduğunu gösteren pek çok çalışma bulunmaktadır (Judge \& Bretz, 1994). Ayrica kendini sevdirme taktiğinin performans değerlemesi bakımından olumlu bir etkisi bulunduğunu gösteren çalışmalar da bulunmaktadir (Ferris \& Judge \& Rowland \& Fitzgibbons, 1994). İzlenim yönetimi taktiklerinden bir diğeri olan niteliklerini tanıtma yönteminin işe alım konusunda pozitif yönde etkili (Barrick \& Shaffer \& DeGrassi, 2009), fakat kariyer başarısı konusunda olumsuz yönde etkili olduğu (Judge \& Bretz, 1994) gösterilmiştir. Ek olarak, niteliklerini tanıtma taktiğinin performans değerlemeleri açısından olumsuz olduğunu gösteren çalışmalar bulunmaktadır (Higgins \& Judge \& Ferris 2003).

Alan yazını taramasında görüldüğü üzere izlenim yönetimi taktiklerinin performans değerlemesi üzerinde anlamı bir etkisi bulunmaktadır. Bu araştırmada literatürde sıklıkla incelenen izlenim yönetimi taktiklerinin performans algısı üzerindeki rolü kurgusu ters çevrilerek bireysel performans algısının izlenim yönetimi taktikleri üzerindeki etkisi incelenmektedir. Ayrıca, literatürde yapılan çalışmalarda genellikle yöneticilerin performans değerlemesi ile izlenim yönetimi taktikleri arasındaki ilişki incelenirken, bu çalışmada bireysel performans algısı ile izlenim yönetimi taktikleri arasındaki ilişki incelenmektedir. $\mathrm{Bu}$ nedenle araştırmanın hipotezleri aşağıdaki gibi kurgulanmıştır: 
$\mathbf{H}_{1}$ : Bireysel performans alg1sı izlenim yönetimi taktiklerini anlamlı bir şekilde etkilemektedir.

H1a: Bireysel performans algis1 izlenim yönetimi taktiği olan kendini sevdirmeyi olumlu yönde etkilemektedir.

H1b: Bireysel performans alg1s1 izlenim yönetimi taktiği olan niteliklerini tanıtmayı olumlu yönde etkilemektedir.

H1c: Bireysel performans alg1sı izlenim yönetimi taktiği olan gözdağı vermeyi olumlu yönde etkilemektedir.

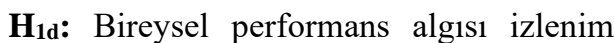
yönetimi taktiği olan örnek olmayı olumlu yönde etkilemektedir.

$\mathbf{H}_{1 \mathrm{e}}$ : Bireysel performans alg1s1 izlenim yönetimi taktiği olan kendini acındırmayı olumlu yönde etkilemektedir.

\subsection{Araştırmanın Evreni ve Örneklemi}

Araştırmanın örneklemini oluşturmak için kolayda örneklem tekniği ile seçilen Türkiye Kömür İşletmeleri'nden (TKİ) gerekli izinler alınarak araştırmacı tarafından derlenen anket formu gerekli birime ulaştırılmıştır. Elde edilen bilgiye göre yaklaşık 700 kişinin istihdam edildiği TKİ'ne 500 adet anket formu ulaştırılmıştır ve 400 adet geri dönüş sağlanmıştır. Elde edilen 400 adet anket formundan 48 adeti eksik veya çoklu cevap verme nedeniyle örnekleme dahil edilmemiştir. Ayrıca analiz öncesinde yapılan çoklu uç değer analizi de göz önünde bulundurularak 37 adet anket formu, araştırmanın sonucunu normal dağılımı engelleyeceği düşüncesiyle analize dahil edilmemiştir. Sonuçta, araştırmanın örneklemini, Türkiye Kömür İşletmeleri'nde çalışan 315 çalışan oluşturmaktadır. Araştırmanın örnekleminin demografik özellikleri aşağıdaki gibi sınıflanmıștır: - Katılımciların 224'ü erkek iken 91'i kadındır.

- Katılımcıların yaş ortalaması 39,8'dir.

- Katılımciların 2'si lise, 69'u ön lisans, 207'si lisans, 35’i yüksek lisans ve 2'si doktora mezunudur.

- Katılımciların mesleki tecrübe ortalaması yıl bazında 15,8 ' dir

\subsection{Araştırmanın Modeli}

Araştırmanın modeli Şekil 1 ile görselleştirilerek sunulmuştur.

\subsection{Araștırmanın Veri Toplama Yöntemleri}

Araştırmada veri toplama amacıyla anket yöntemi kullanılmıştır. Araştırmacı tarafından derlenen anket formu izlenim yönetimi taktikleri ölçeği, bireysel performans değerlendirme ölçeği ve demografik bilgileri saptamaya yönelik ölçek olmak üzere üç farklı ölçekten oluşmaktadır. Demografik bilgileri saptamaya yönelik ölçekte katılımcıların cinsiyeti, eğitim durumu, yaşı ve mesleki tecrübelerini saptama amaciyla sorular bulunmaktadır.

İzlenim Yönetimi Taktikleri Ölçeği. Araştırmada kullanılan bu ölçek Jones ve Pittman (1982) tarafindan ortaya atılan izlenim yönetimleri taktikleri kullanılarak Bolino ve Turnley (1999) tarafından geliştirilmiştir. Basım ve arkadaşlarının (2006) Türkçe’ye uyarlamış oldukları bu ölçek 5’li Likert tipinde hazırlanmakla beraber 22 madde ve 5 farklı boyuttan oluşmaktadır. Bu boyutlar "Kendini acındırma", "Kendi önemini zorla fark ettirme",

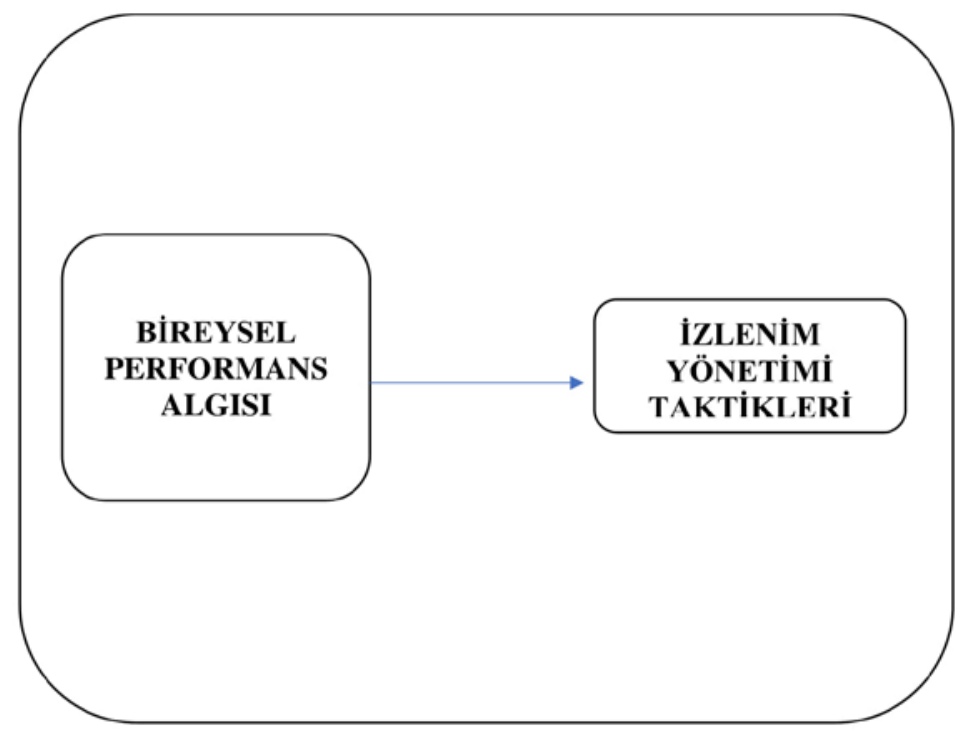

Şekil 1: Araştırmanın Modeli 
Tablo 1: İzlenim Yönetimi Taktikleri Ölçeği Uyum Endeksleri

\begin{tabular}{lcccc}
\hline$\chi^{\mathbf{2}[\mathbf{N}=\mathbf{3 1 5}]}$ & $\chi^{\mathbf{2} / \mathbf{d f}}$ & RMSEA & CFI & GFI \\
\hline 56,188 & 2,71 & 0,08 & 0,96 & 0,95 \\
\hline $\mathrm{p}>.05$ & & & &
\end{tabular}

Tablo 2: Bireysel Performans Değerlendirme Ölçeği Uyum Endeksleri

\begin{tabular}{ccccc}
\hline$\chi^{2}[\mathbf{N}=\mathbf{3 1 5}]$ & $\chi^{2 / \mathbf{d f}}$ & RMSEA & CFI & GFI \\
\hline 77,946 & 2,38 & 0.07 & 0,94 & 0,95 \\
\hline $\mathrm{p}>.05$ & & & &
\end{tabular}

“İşine sahip çıkma”, "Kendini örnek personel gibi gösterme" ve "Niteliklerini tanıtarak kendini sevdirme" şeklinde adlandırılmaktadır. $\mathrm{Bu}$ araştırmada da Basım ve arkadaşlarının (2006) kullanmış oldukları faktör yapısı ele alınarak doğrulayıcı faktör analizi AMOS programı kullanılarak gerçekleştirilmiştir. Aşağıda bulunan Tablo 1'de doğrulayıcı faktör analizi sonucunda elde edilen uyum endeks değerleri bulunmaktadır. Elde edilen sonuçlar doğrultusunda ölçeğin beş faktörlü yapısının geçerli olduğu saptanmıştır.
Bireysel Performans Değerlendirme Ölçeği. Borman ve Motowidlo (1993) ile Beffort ve Hattrup (2003) tarafından oluşturulan ölçek Türkçeye Karakurum (2005) tarafindan geliştirilerek uyarlanmıştır. Ölçek beşli Likert tipi şeklinde "tamamen katılıyorum=5" seçeneği ile "kesinlikle katılmıyorum=1" aralığında tasarlanmıştır. Toplam 11 ifadeden oluşmaktadır. Ölçekteki altı ifade görev performansını, beş ifade ise durum performansını ölçmektedir. Aşağıda bulunan Tablo 2'de doğrulayıcı faktör analizi sonucunda elde edilen uyum indeks değerleri bulunmaktadır. Elde edilen

Tablo 3: Regresyon Analizi Sonuçları

\begin{tabular}{|c|c|c|c|c|c|c|}
\hline Model & $\beta$ & T Değeri & Sig. & $\mathbf{R}$ & $\mathbf{R}^{2}$ & Düzeltilmiş $\mathbf{R}^{2}$ \\
\hline 1 & & & & 0,347 & 0,120 & 0,104 \\
\hline $\begin{array}{l}\text { Sabit Değer (Bireysel } \\
\text { Performans Algısı) }\end{array}$ & 3,326 & 11,653 & 0,000 & & & \\
\hline $\begin{array}{l}\text { İlenim Yönetimi } \\
\text { Taktikleri }\end{array}$ & 0,245 & 2,720 & 0,000 & & & \\
\hline 1a & & & & 0,289 & 0,083 & 0,058 \\
\hline $\begin{array}{l}\text { Sabit Değer (Bireysel } \\
\text { Performans Algısı) }\end{array}$ & 3,558 & 11,907 & 0,000 & & & \\
\hline Kendini Sevdirme & 0,176 & 1,784 & 0,000 & & & \\
\hline $1 \mathrm{~b}$ & & & & 0,298 & 0,089 & 0,086 \\
\hline $\begin{array}{l}\text { Sabit Değer (Bireysel } \\
\text { Performans Algısı) }\end{array}$ & 4,979 & 40,696 & 0,000 & & & \\
\hline Niteliklerini Tanıtma & 0,284 & 5,451 & 0,000 & & & \\
\hline 1c & & & & 0,128 & 0,016 & $-0,02$ \\
\hline $\begin{array}{l}\text { Sabit Değer (Bireysel } \\
\text { Performans Algısı) }\end{array}$ & 3,829 & 14,260 & 0,000 & & & \\
\hline Gözdağı Verme & 0,096 & 0,948 & 0,347 & & & \\
\hline 1d & & & & 0,274 & 0,075 & 0,061 \\
\hline $\begin{array}{l}\text { Sabit Değer (Bireysel } \\
\text { Performans Algısı) }\end{array}$ & 3,596 & 13,886 & 0,000 & & & \\
\hline Örnek Olma & 0,164 & 1,934 & 0,000 & & & \\
\hline $1 \mathrm{e}$ & & & & 0,112 & 0,013 & $-0,06$ \\
\hline $\begin{array}{l}\text { Sabit Değer (Bireysel } \\
\text { Performans Algısı) }\end{array}$ & 3,902 & 17,782 & 0,000 & & & \\
\hline Kendini Acındırma & 0,069 & 0,830 & 0,410 & & & \\
\hline
\end{tabular}


veriler uyarınca ölçeğin iki faktörlü yapısının doğrulandığı sonucuna varılmıştır.

\section{BULGULAR}

Bireysel performans algısının izlenim yönetimi taktikleri üzerindeki etkisini ölçmeye yönelik oluşturulan hipotezlerin test edilmesi amacıyla SPSS (Versiyon 22.00) programı kullanılarak Enter metoduyla basit regresyon analizi uygulanmıştır. Sahip olunan verinin regresyon analizine uygunluğunu test etmek amacıyla yapılan normallik testinin sonuçları pozitif çıkmıştır. Aşağıdaki tabloda regresyon modelinin uygunluğunu test etmek amaciyla uygulanan ANOVA testinin sonuçları bulunmaktadır. Elde edilen sonuçlar uyarınca $(p<0,05)$ olmasi nedeniyle modelin regresyon analizine uygun olduğu sonucuna varılmıştır. Tablo 3 'te regresyon analizinin sonuçlar gösterilmektedir.

Elde edilen bulgular sonucunda izlenim yönetimi taktiklerinin bireysel performans algısından anlamlı ve pozitif bir şekilde etkilendiği sonucuna ulaşılmıştır. İzlenim yönetimi taktiklerinden olan kendini sevdirme, niteliklerini tanıtma ve örnek olma davranışlarının bireysel performans algısından anlamlı ve pozitif bir şekilde etkilendiği sonucuna ulaşılmıştır. Gözdağı verme ve kendini acındırma izlenim yönetimi taktiklerinin bireysel performans algısından etkilenmediği sonucuna ulaşılmıştır.

\section{SONUÇ VE TARTISMA}

Aşağıdaki tabloda yapılan analiz sonucunda hipotezlerin onaylanıp onaylanmadığına ilişkin bulgular bulunmaktadır. Yapılan analizlerin sonucuna göre bireysel performans algısının izlenim yönetimi taktiklerini anlamlı bir şekilde etkilediği sonucuna ulaşılmıştır.

Örgüt üyelerinin izlenim yönetimi taktiklerini kullanmaları örgüt içerisindeki konumlarının bilincinde olduklarını ve kendilerini ifade etme ve imajlarını yönetme konusunda başarılı olduklarını göstermektedir. Bilinçli olarak sürdürülen izlenim yönetiminin bireysel performans algısından etkilendiği sonucuna ulaşılmasıyla birlikte kendini sevdirme, niteliklerini tanıtma ve örnek olma boyutlarının bireysel performans algısının yüksek olmasıyla ilişkili olduğu görülmüştür. Yani, bireysel performans algısı yüksek olan örgüt üyeleri bu üç yönteme başvurmaktadır. Düzeltilmiş R2 değerleri incelendiğinde, kendini sevdirme boyutu $\% 5,8$, niteliklerini tanıtma boyutu \%8,6 ve örnek olma boyutu $\% 6,1$ oranında bireysel performans alg1S1 ile açıklanabilmektedir.

Araştırmanın daha önceki bölümlerinde bahsedildiği üzere izlenim yönetimi taktikleri hem günlük hayatta hem de örgüt içerisinde sıklıkla başvurduğu birer iletişim yöntemidir. Genellikle bir kişiye veya gruba karşı imajını yönetme ihtiyacı taşıyan insanların sözlü veya sözsüz iletissim kanallarını kullanarak izlenim yönetimi taktiklerine başvurdukları görülmektedir. $\mathrm{Bu}$ araştırma sonucunda da bir iletișim aracı olarak izlenim

Tablo 4: Analiz Sonrası Hipotezlerin Onay Durumu

\begin{tabular}{cll}
\hline Hipotez No & \multicolumn{1}{c}{ Açıklama } & \multicolumn{1}{c}{ Sonuç } \\
\hline $\mathbf{H}_{\mathbf{1}}$ & Bireysel performans algısı izlenim yönetimi taktiklerini & Onaylandı \\
& anlamlı bir şekilde etkilemektedir. & \\
\hline $\mathbf{H}_{\mathbf{1 a}}$ & Bireysel performans algısı izlenim yönetimi taktiği olan & Onaylandı \\
& kendini sevdirmeyi olumlu yönde etkilemektedir. & \\
\hline $\mathbf{H}_{\mathbf{l b}}$ & Bireysel performans algısı izlenim yönetimi taktiği olan & Onaylandı \\
& niteliklerini tanıtmayı olumlu yönde etkilemektedir. & \\
\hline $\mathbf{H}_{\mathbf{l c}}$ & Bireysel performans algısı izlenim yönetimi taktiği olan & Onaylanmadı \\
& gözdağı vermeyi olumlu yönde etkilemektedir. & \\
\hline $\mathbf{H}_{\mathbf{l d}}$ & Bireysel performans algısı izlenim yönetimi taktiği olan & Onaylandı \\
& örnek olmayı olumlu yönde etkilemektedir. & \\
\hline $\mathbf{H}_{\mathbf{l e}}$ & Bireysel performans algısı izlenim yönetimi taktiği olan & Onaylanmadı \\
& kendini acındırmayı olumlu yönde etkilemektedir. & \\
\hline & &
\end{tabular}


yönetiminin bireysel performans algısı üzerinde anlamlı bir etkisi olduğu görülmüştür. Yani, sözlü ve sözsüz iletişim kanallarını kullanarak izlenim yönetimi taktiklerinden kendini sevdirme, niteliklerini tanıtma ve örnek olma bireysel performans algısını anlamlı ve olumlu bir şekilde etkilemektedir.

Alan yazını incelendiğinde bireysel performans algısının izlenim yönetimi taktikleri üzerindeki etkisini inceleyen herhangi bir araştırmaya rastlanılamamıştır. $\mathrm{Bu}$ açıdan, bu çalışmanın literatürdeki eksikliği kapatması hedeflenmektedir. Alan yazınında genellikle, izlenim yönetimi ve performans değerlendirmesi arasındaki bağlantı araştırmalara konu olmuştur. $\mathrm{Bu}$ araştırmalarda performans ölçüsü bireysel algılanan performans yerine yöneticilerin yapmış olduğu performans değerlendirmeleri kullanılmıştır.

Araştırmada elde edilen sonuçlar benzer çalışmalarda elde edilen sonuçlar ile kısmen tutarlılık göstermektedir (Ingold \& Kleinmann \& König \& Melchers, 2014; Ispas vd., 2014). Yapilan araştırmalar izlenim yönetimi taktikleri ile performans arasinda anlamlı ve pozitif bir korelasyon bulunduğunu göstermektedir (Semadar \& Robins \& Ferris, 2006). Fakat daha önce bahsedildiği gibi bu çalışmalar astın izlenim yönetimi ile üstün performans değerlendirmesi üzerine kurgulanmıştır. $\mathrm{Bu}$ araştırmada ise hem izlenim yönetimi hem de performans bireysel olarak değerlendirilmektedir.

Araştırmanın sonuçları değerlendirilirken, araştırmanın sahip olduğu sinırlılıklar göz ard1 edilmemelidir. Bu araştırmanın en önemli sınırlılığ Ankara'da Türkiye Kömür İşletmeleri'nde çalışan kişilerden oluşan bir örneklem kullanılmasıdır. Ayrıca, katılımcıların ankette belirtilen ifadeleri doğru bir şekilde anlayarak dürüst bir biçimde cevap verdikleri varsayılmaktadır. Gelecekte izlenim yönetimi ve bireysel algılanan performans konusunda yapılacak olan çalışmalarda araştırmacılar farklı örgütlerde çalışan insanlardan oluşan bir örneklem kullanmasının faydalı olacağı düşünülmektedir. Ayrıca benzer bir araştırma kurgusu ile bu araştırmanın özel sektör kuruluşlarında uygulanmasının faydalı olacağı düşünülmektedir. Ek olarak, gelecekte izlenim yönetimi ve bireysel performans algısı konularında yapılacak olan çalışmalarda farklı örgütsel davranış kavramları da kullanılmasının faydalı olacağı düşünülmektedir.

\section{ETIKK BEYANATI}

Destek Bilgisi: $\mathrm{Bu}$ çalışma, kamu, ticari veya kar amac1 gütmeyen kuruluşlar gibi herhangi bir organizasyondan destek almamıştır.

Çıkar Çatışması: Sorumlu yazar çıkar çatışması olmadığını belirtir.

Etik Onay: İnsan katılımcıları içeren çalışmalarda gerçekleştirilen tüm prosedürler, kurumsal ve / veya ulusal araştırma komitesinin etik standartlarına ve 1964 Helsinki deklarasyonuna ve daha sonraki değişikliklerine veya karşılaştırılabilir etik standartlara uygundur.

Bilgilendirilmiş Onam Formu: Çalışmaya katılan tüm bireysel katılımcılardan bilgilendirilmiş onam formu alınmıştır. 


\section{KAYNAKÇA}

Akçakanat, T. (2009). Insan kaynaklarl yönetiminde performans değerlendirme: Isparta il Emniyet Müdürlüğü'nde bir uygulama (Yayımlanmamış Doktora Tezi), Süleyman Demirel Üniversitesi, Sosyal Bilimler Enstitüsü, Isparta.

Akgün, T. (2009). İzlenim yönetimi taktikleri ile iş performansı değerleme puanları arasındaki ilişki: Bir uygulama.

Arkin, R. M., Shepperd, J. A., Giacalone, R., \& Rosenfeld, P. (1989). Self-presentation styles in organizations. Impression Management in The Organization, 1(1), 125-139.

Barrick, M. R., Shaffer, J. A., \& DeGrassi, S. W. (2009). What you see may not be what you get: relationships among self-presentation tactics and ratings of interview and job performance. Journal of Applied Psychology, 94(6), 1394.

Basım, N., Tatar, İ., \& Şahin, N. H. (2006). Çalışma yaşamında izlenim yönetimi: Bir ölçek uyarlama çalışması. Türk Psikoloji Yazıları, 9(18), 1-17.

Beffort, N. \& Hattrup, K. (2003) Valuing task and contextual performance: Experience, job roles, and ratings of the importance of job behaviors. Applied H.R.M. Research, 8(1), 17-32

Bolino, M. C. (1999). Citizenship and impression management: good Soldiers or good actors? Academy of Management Review, 24(1), 82-98. https://doi.org/10.5465/AMR.1999.1580442

Bolino, M. C., \& Turnley, W. H. (1999). Measuring impression management in organizations: A scale development based on the Jones and Pittman Taxonomy. Organizational Research Methods, 2(2), 187-206. https://doi.org/10.1177/109442819922005

Bolino, M. C., Kacmar, K. M., Turnley, W. H., \& Gilstrap, J. B. (2008). A multi-level review of impression management motives and behaviors. Journal of Management, 34(6), 1080-1109.

Borman, W. C., \& Motowidlo, S. M. (1993). Expanding the criterion domain to include elements of contextual performance. In Schmitt N. ve Borman W.C. (Eds.) Personnel Selection in Organizations, San Francisco: Jossey Bass, 71-98.

Bourdage, J. S., Wiltshire, J., \& Lee, K. (2015). Personality and workplace impression management: correlates and implications. The Journal of Applied Psychology, 100(2), 537-546. https://doi.org/10.1037/a0037942

Çetin, F., \& Basım, H. (2010). İzlenim yönetimi taktiklerinde öz yeterlilik algısının rolü. Erciyes
Üniversitesi İktisadi ve İdari Bilimler Fakültesi Dergisi, (35), 255-269.

Çöl, G. (2008). Algılanan güçlendirmenin işgören performansı üzerine etkileri. Doğuş Üniversitesi Dergisi, 9(1), 35-46.

Doğan, S., \& Kılıç, S. (2009). Örgütlerde “izlenim yönetimi davranışı" üzerine kavramsal bir inceleme. Atatürk Üniversitesi İktisadi ve İdari Bilimler Dergisi, 23(3), 53-83.

Ferris, G. R., Judge, T. A., Rowland, K. M., \& Fitzgibbons, D. E. (1994). Subordinate influence and the performance evaluation process: Test of a model. Organizational Behavior and Human Decision Processes, 58(1), 101-135.

Gardner, W. L. (1992). Lessons in organizational dramaturgy: The art of impression management. Organization al Dynamics, 21(1), 33-46. https://doi.org/10.1016/0090-2616(92)90084-Z

Goffman, E. (1959). The presentation of self in everyday life. New York: Garden City.

Higgins, C. A., Judge, T. A., \& Ferris, G. R. (2003). Influence tactics and work outcomes: A metaanalysis. Journal of Organizational Behavior: The International Journal of Industrial, Occupational and Organizational Psychology and Behavior, 24(1), 89106.

Ingold, P., V., Kleinmann, M., König, C.J., Melchers, K.G. (2014). Shall we continue or stop disapproving of self-presentation? Evidence on impression management and faking in a selection context and their relation to job performance, European Journal of Work and Organizational Psychology, 24(3), 420432.

Ispas, D., Iliescu, D., Ilie, A., Sulea, C., Askew, K., Rohlfs, J.T. Whalen, K. (2014). Revisiting the relationship between impression management and job Performance, Journal of Research in Personality, 51, $47-53$

Jain, A. (2012). Does emotional intelligence predict impression management? Journal of Organizational Culture Communications and Conflict, 16(2), 11-25.

Jaja, S. A. (2003). Impression management metaphors: an agenda for the 21. century african industrial managers. Management Research News, 26(12), 7394.

Jones, E. E., \& Pittman, T. S. (1982). Toward a general theory of strategic self-presentation. Psychological Perspectives on the Self, 1(1), 231-262.

Judge, T. A., \& Bretz Jr, R. D. (1994). Political influence behavior and career success. Journal of Management, 20(1), 43-65. 
Karakurum, M. (2005). The effects of personhttps://doi.org/10.5465/AMR.1987.4307820 organization fit on employee job satisfaction, performance and organizational commitment in a Turkish public organization. (Unpublished Master Thesis).

Luecke, R. (2008). Performans yönetimi. Çeviren: Aslı Özer, İstanbul: Türkiye İş Bankası Kültür Yayınları.

Montagliani, A., \& Giacalone, R. A. (1998). Impression management and cross-cultural adaption. Journal of Social Psychology, 138(5), 598-607. https://doi.org/10.1080/00224549809600415

Özdemir, G. (2006). Organizasyonlarda kişilerarası ilişkilerde etki taktikleri ve kullanımına ilişkin literatür çalışması. Bilig - Türk Dünyası Sosyal Bilimler Dergisi, Kış (36), 93-112.

Peck, J. A., \& Hogue, M. (2018). Acting with the best of intentions... or not: A typology and model of impression management in leadership. Leadership Quarterly, 29(1), 123-134. https://doi.org/10.1016/j.leaqua.2017.10.001

Rosenfeld, P., Giacalone, R.A. \& Riordan, C.A. (1995). Impression management in organizations: Theory, measurement, practice. London and New York: Routhledge.

Semadar, A., Robins, G., Ferris, G..R. (2006). Comparing the validity of multiple social effectiveness constructs in the prediction of managerial job performance. Journal of Organizational Behaviour, 27, 443-461

Singh, V., Vinnicombe, S. (2001), Impression management, commitment and gender: managing others' good opinions. European Management Journal, 19(2), 183- 194.

Türk Dil Kurumu (TDK), İzlenim, https://kelimeler.gen.tr/izlenim-nedir-ne-demek170448

Toptan, M. (2014). Muhasebe meslek mensuplarinin kullandiklarl izlenim yönetimi taktiklerinin belirlenmesi: Trabzon ve Rize illerine yönelik bir uygulama, (Yayınlanmamış Doktora Tezi), Recep Tayyip Erdoğan Üniversitesi/Sosyal Bilimler Enstitüsü, Rize.

Tunçer, P. (2013). Örgütlerde performans değerlendirme ve motivasyon. Sayıştay Dergisi, 88(1), 87-108.

Yu, K. Y. T. (2019). Influencing how one is seen by potential talent: Organizational impression management among recruiting firms. Journal of Applied Psychology, 104(7), 888-906. https://doi.org/10.1037/apl0000386

Zerbe, W. J., \& Paulhus, D. L. (1987). Socially desirable responding in organizational behavior: a reconception. Academy of Management Review, 12(2), 